\title{
25. Shale gas for energy security in India: Perspectives and constraints
}

\author{
Asit K. Biswas \\ Lee Kuan Yew School of Public Policy, Singapore \\ Julian Kirchherr \\ Lee Kuan Yew School of Public Policy, Singapore
}

India lacks energy. In 2011, almost 300 million people - 25 per cent of the country's population - had no access to electricity. Even 65 years after independence, only nine states - Andhra Pradesh, Gujarat, Karnataka, Goa, Delhi, Haryana, Kerala, Punjab, and Tamil Nadu - out of a total of 28 have been officially declared as electrified (British Broadcasting Corporation (BBC) 2012). But even in these so-called electrified states, power shortages and power cuts are often common. In July 2012, the worst energy blackout in a decade left more than 620 million Indians without electricity, and total energy demand currently outstrips supply by as much as 15 per cent.

Chronic energy shortages and unreliable supplies threaten India's economic growth. For investors, continuous and reliable supplies of energy are essential requirements for any ventures. According to estimates by HDFC Bank, the country's chronic energy shortages have already slowed down GDP growth from 8 per cent to 6.5 per cent (Economic Times 2012). With accelerating energy demand, poor management, political and institutional inertia and bureaucratic constraints, India's energy gap is likely to remain for at least the next two decades. Policy-makers are urgently seeking solutions to ensure that the economy is not starved of energy.

\section{Shale gas in India}

Shale gas is a possible solution and the Indian Government plans to exploit the country's shale gas resources to address the country's energy problems. In September 2013 a shale gas exploration policy was released allowing two state-run institutions, Oil and Natural Gas Corporation and Oil India Limited, to explore shale gas that was previously allotted to them on a nomination basis. During the next phase, the government may offer shale oil and gas blocks to other companies. 
It has been estimated that India may have recoverable shale gas reserves of as much as 96 trillion cubic feet; the exact amount is still unknown (livemint 2012). Large reserves have been confirmed in Khambhat, Assam-Arakan, Gondawana, and Cauvery. Currently, gas accounts for approximately 11 per cent of the country's energy mix, nearly half of energy consumed is generated from coal, followed by hydropower at 25 per cent.

Shale gas now receives attention in many countries of the world. The International Energy Agency (IEA) has even announced that the world could enter a 'golden age of gas' (2011). Indeed, shale gas has turned the US energy market on its head and the country is about to switch from being a gas importer to a major exporter. ${ }^{1}$ China, which is estimated to hold the world's largest shale gas resources, aims to replicate this American success story, with plans to produce as much as 3500 billion cubic feet of shale gas annually by 2020 .

\section{Technological and hydrological constraints on shale gas development}

While the excitement in India over shale gas is understandable, it may be premature for two reasons.

First, India lacks the technological capabilities necessary to access its reserves. Hydraulic fracturing, commonly known as fracking, is the sophisticated and complex technique by which shale gas is exploited. Currently, only North America - with its favourable geology - has been able to exploit shale gas commercially on a large scale. India would have to enter countless strategic and long-term partnerships with foreign governments and private sector companies to acquire these technologies and skills and adapt them to its specific geology. This will take time and is unlikely to be as straight-forward as its proponents suggest.

Second, extensive exploitation of shale gas in India is likely to devastate the country's water resources, offsetting any social benefit from increased energy production by worsening India's water crisis. The main constraint in this regard is likely to be India's failure to treat wastewater. Exploiting shale gas requires massive amounts of water which becomes heavily contaminated during the exploitation process (Cooley and Donnelly 2012). There is now considerable uncertainty over whether it is possible to cost-effectively recycle shale gas wastewater (Ferrar et al. 2013). Because the growth of the American industry has outpaced regulatory guidelines, it is not yet possible to test systematically

1 The US shale gas industry grew by 45 per cent per year between 2005 and 2010 (Economist 2012a), reducing the American gas price from US\$30.00 to as little as US\$03.00 per million British thermal units (mBtu) (Economist 2012b). 
and objectively if the treatment has been sufficient or appropriate. It is known, however, that the exploitation of shale gas can lead to the migration of toxic injection fluids into water sources, which may later be used for drinking, and contamination of groundwater by released methane gas also entails a range of health risks. ${ }^{2}$

India is, sadly, a world leader in water pollution: the Holy Ganges contains more than 60,000 faecal coliform bacteria per 100 millilitres in many parts, which is 120 times more than what is considered safe for bathing (Economist 2008). In most parts of the country, including the capital region Delhi, sewage is disposed of to nearby rivers without any treatment. This is because India lacks sufficient treatment capacity and, even where such treatment plants exist, their proper operation and maintenance practices have been often poor.

In a country with such a record of wastewater treatment, it may be unrealistic to expect that wastewater from shale gas exploitation would be adequately treated. Indeed, even in the United States, with its record of wastewater treatment, there have been many reports of improperly disposed toxic wastewater from the fracking process. If India acquired the necessary technology and expertise to exploit shale gas, it may still fail to treat the resulting wastewater. Such a failure may offset any energy gain. For India's poor, clean water often may be more important than access to energy.

For fracking to be practiced widely in India, the country will also have to allocate significant new sources of water. At present, because of poor management of water, the country is facing serious scarcity of water in most regions (Biswas 2011). The interstate disputes on water are already fierce and the water available in the country is already over-allocated. The groundwater levels in provinces like Punjab, Haryana, Rajasthan, Gujarat and Maharashtra are declining precipitously. There is not a single important city which can provide 24-hour water supply to its citizens. Since water is free or heavily subsidised, and there is significant political opposition to water pricing, widespread water conservation is an unrealistic proposition for the foreseeable future. Under these conditions, it is unlikely that India will be able to divert water to a new, intensive use like fracking.

\section{Outlook}

The global perception of shale gas and its potential is still evolving. Hence, India may take the wrong path if it attempts to exploit its shale gas resources without considering the serious and unintended consequences.

2 See Hildenbrand et al. (2014) in this volume for further discussion of fracking impacts on groundwater quality. 
India must first carefully reassess the size and value of its recoverable shale gas reserves and weigh the potential benefits against the risks, particularly those related to water. Only if sufficient reserves are available and more pressing policy challenges are faced, should India then continue to build up its technological shale gas capabilities.

Notably, India has already started to emphasise addressing some of the relevant policy challenges, particularly improving energy use and water efficiency. Faced with looming water and energy scarcities, many major industrial concerns are changing their industrial processes and practices. ${ }^{3}$

Despite such positive trends, India's energy and water problems will most certainly continue to increase if the aspirations and expectations of its people are to be met. For example, India is now already the fourth largest energy consuming country of the world, yet its per capita energy consumption is low and it will continue to increase for decades, irrespective of all conservation measures. The country has to focus on the difficult task of concurrently expanding its energy sources and increasing energy conservation. Proponents will likely continue to propose shale gas as an option to address the first of these challenges.

On the other hand, water has become an increasingly critical resource in the country, primarily because of poor management. During the campaign for the 2014 general election, for the first time water has become a part of the electoral strategy of all the major parties. Thus, there is no question that current and future water scarcities mean widespread fracking, even if it was possible at present, is not a viable option. Furthermore, legal and administrative arrangements for the land acquisition required for fracking are more complicated in India compared to the United States, and there are also the aforementioned technological barriers.

In some ways, these constraints may prove to be a blessing in disguise for the country. The delay in solving the institutional, legal, land and water-related problems will take at least a decade to overcome. One hopes that during this period the country can assess carefully and objectively the economic benefits and social and environmental costs of fracking so that the right decision can be made for the future.

Asit K. Biswas is the Distinguished Visiting Professor at the Lee Kuan Yew School of Public Policy, Singapore, and Founder of Third World Centre for Water Management.

Julian Kirchherr is a former Research Associate at the Lee Kuan Yew School of Public Policy.

3 For example, between 1997-2012, Nestlé India reduced its water requirements to produce a tonne of product by 74.3 per cent, and energy needs by 65 per cent (Authors' research). 


\section{References}

Biswas, A.K., 2011. 'Urban water management in India: akin to a banana republic', New Global Indian, August.

—_ Tortajada, C., Biswas-Tortajada, A., Joshi, Y. K. and Gupta, A. 2013. Creating Shared Value: Impacts of Nestlé in Moga, India, Springer, Berlin, pp. 68-70.

British Broadcasting Corporation (BBC), 2012. 'Ten interesting things about India power', 31 July. Available at: http://www.bbc.co.uk/news/world-asiaindia-19063241.

British Petroleum (BP), 2012. 'Energy outlook 2030', London.

Business Standard, 2012. 'Why Indian firms are so high on shale gas', 16 October. Available at: http://www.business-standard.com/article/companies/whyindian-firms-are-so-high-on-shale-gas-112101600048_1.html.

Cooley, H. and Donnelly, K., 2012. 'Hydraulic fracturing and water resources: separating fact from fiction', Pacific Institute, California.

Exxon Mobil, 2013. 'The outlook for energy: a view to 2040'.

Ferrar, K.J., Michanowicz, D.R., Christen, C.L., Mulchay, N., Malone, S.L. and Sharma, R.K.,. 2013. 'Assessment of effluent contaminants from three facilities discharging marcellus shale wastewater to surface waters in Pennsylvania', Environmental Science \& Technology 47(7):3472-81.

Guardian, 2012. 'India power outage hits 350m people', 30 July. Available at: http://www.theguardian.com/world/2012/jul/30/india-power-outage-350mpeople.

International Energy Agency (IEA), 2011. 'World energy outlook 2011 special report: are we entering a golden age of gas?'. Available at: http:// www.worldenergyoutlook.org/goldenageofgas/.

Hildenbrand et al. (2014) 'New perspectives on the effects of natural gas extraction on groundwater quality', in R.Q. Grafton, P.R. Wyrwoll, C. White and D. Allendes (eds), Global Water: Issues and Insights, ANU Press, Canberra.

livemint, 2012. 'Shale gas exploration policy by month-end: oil secretary', 11 December. Available at: http://www.livemint.com/Industry/ vOer4JUAznAmwDcNRFbhDO/Shale-gas-exploration-policy-by-monthendoil-secretary.html. 
Moneycontrol, 2012. 'Shale gas exploration policy by month end', 12 December. Available at: http://www.moneycontrol.com/news/business/shale-gasexploration-policy-by-month-end_793787.html.

Osborn, S.G., Vengosh, A., Warner, N.R. and Jackson, R.B., 2011. 'Methane contamination of drinking water accompanying gas-well drilling and hydraulic fracturing', Proceedings of the National Academy of Sciences of the United States of America 108(37):8172-6.

Economic Times, 2011. 'Energy deficit may rise up to $15 \%$ as weak rupee hurts coal imports', 26 December. Available at: http://articles.economictimes. indiatimes.com/2011-12-26/news/30559123_1_coal-imports-ashok-kumarkhurana-weak-rupee.

The Economist, 2008. 'Creaking, groaning: Infratructure is India's biggest handicap', 11 December. Available at: http://www.economist.com/ node/12749787.

- 2012a. 'Shale of the century', 2 July. Available at: http://www.economist. com/node/21556242.

— , 2012b. 'Shale: can the US experience be repeated?' , 13 September. Available at: http://www.economist.com/blogs/buttonwood/2012/09/energy. 
This text taken from Global Water: Issues and Insights by R. Quentin Grafton, Paul Wyrwoll, Chris White and David Allendes, published May 2014 by ANU Press, The Australian National University, Canberra, Australia. 